\title{
Description of the Quality of Life of Teachers for Special Needs Students During the Pandemic of COVID-19
}

\author{
Pamela Hendra Heng ${ }^{1 *}$ Riana Sahrani ${ }^{1}$ Nurhayati Silalahi ${ }^{1}$ \\ ${ }^{1}$ Faculty of Psychology, Universitas Tarumanagara, West Jakarta, 11440, Indonesia \\ "Corresponding author. Email: pamelah@fpsi.untar.ac.id
}

\begin{abstract}
During the COVID-19 pandemic, all activities were limited and carried out from home. It also includes learning that must be done from home, so that can affect the quality of life for teachers, especially for Special Needs or ABK teachers. The purpose of this study was to describe the quality of life of the ABK teachers during the pandemic. Participants in this study were 101 teachers of children with special needs, who were categorized as early adults and middle adults aged 20-65 years. The design of this research is non-experimental quantitative, using tools measure in the form of a questionnaire. The measuring instrument used to measure the quality of life for ABK teachers is WHOQOL-BREF which was adapted by Purba et. al. based on the quality of life domain, namely physical, psychological, social relations and social environment. The results of this study show that the quality of life of the ABK teachers is in the high category.
\end{abstract}

\section{Keywords: Quality of life, teacher of special needs students, online learning, COVID-19 pandemic}

\section{INTRODUCTION}

The Corona virus is known to have first spread in a city in China and that city is Wuhan around December 2019 [2]. It spread so quickly that no more than a month later, the virus had already spread in several countries. Because the spread of COVID-19 is very fast and spread to many countries, the World Health Organization (WHO) [3] announced that the incident as a pandemic.

On 10 October 2020, the WHO announced that the number of cases in the world was 36.616.555 where new cases increased by 250.000 per day and spread across 231 countries. From the 36.616 .555 cases, there where 328.952 cases in Indonesia [4]. The global spread is known as a pandemic COVID-19 has resulted in changes in various fields and aspects human life.

The COVID-19 pandemic has brought major changes to the health aspect. Lots of places are taking steps through the application of physical and social distancing to prevent it transmission from one person to another, but this step disrupts the routine of daily life. This has had a major impact on education. Many schools have closed as reports from the United Nations Educational, Scientific and Cultural Organization (UNESCO) in Lee [5] where more than $90 \%$ (1,5 billion) of students registered are unable to continue their education due to school closures.

The impact on the educational aspect is not only felt by students and students but also teaching staff. A study by Schmidt and Ramot [6] said some teachers in Israel had to make quick decisions on curriculum and a syllabus that must be adapted to a pandemic situation. They had to make a long distance learning system and not knowing for sure how long this system will take place. They are faced with technological tools that forces them to break out of their regular comfort zone and engages students in an interactive and collaborative manner. They must try to improve their skill in online teaching, seeking professional development assistance to improve technical-pedagogical skill, and strives to use a variety of teaching tools, offered by institutions, they also receive training and even personal tutorials to help them learn the tools first. Only during the first three weeks they experienced constraints, anxiety, pain, and full of turmoil in adapting to the teaching system new. After that they already feel familiar, comfortable, and competent in using it.

Not all teachers are as fortunate as teachers is Israel in the face of change because of the COVID-19 pandemic. In India, a study by Bhat, Singh, Naik, Kamath, Mulimani and Kulkarni [7] a group of teachers felt dissatisfied and disappointed over the attitude of students, while teachers had to return to work as usual, namely attending school. This creates a psychological impact on the morale of the teachers because there are several senior teachers who have been categorized old age who are included in the vulnerable group of contracting COVID-19. They are haunted by anxiety and fear of returning to family and society. That's why teachers call on the Indian government to think about how to balance between keeping teachers engaged in academia without endangering their life.

Regarding anxiety during the COVID-19 pandemic, a group of teachers in Philippines are also experiencing it. Based on research conducted by Talidong and Toquero [8] said that anxiety arises because teachers are unable do the things they used to do because they are now. Their lifestyle is already changed during a pandemic. The teachers also felt anxious for his safety and their loved ones such as children, mothers, 
fathers, and families. This anxiety affects their lifestyle. To overcome this anxiety, they try having a positive outlook on life amid the COVID-19 pandemic. They do things like always carrying alcohol disinfectant when they go out of the house, reading books, watching television, cooking, playing mobile games, sleeping, and exercising.

Teachers in Indonesia cannot be separated from the impacts and changes caused by the COVID-19 pandemic. In his research, Rokhani [9] explains that the teachers at SD Dengkek 01 finally took all of their work and did it form home. In addition to positive impacts such as feeling safe at work because they are protected from COVID-19, reducing the cost of transportation from home to school, they are also affected negative, that is, there is a feeling of saturation because of the monotonous atmosphere, the interaction with the other teachers and students are reduced, the quality of the learning process decreases, and a decline in the focus on work because of the interaction with family members while teaching with the online system. In a new report, Tribun Jabar [10] reported that a resident felt that it was alright in insulting teachers eating blind salaries because the school never opens. For the insult some teachers beat the residents and reported them to the police.

Although some universities such as the Open University in Indonesia have long use an online system, but an online system is not commonplace and common for students in many schools. In a short conversation through WhatsApp conducted by researchers to four $\mathrm{ABK}$ teachers from Sekolah Luar Biasa Negeri (SLB)-A in Sumatera Utara, SLB-B in Ambon, SLB-C in Batam, and SLBN- D in Yogyakarta. Teacher from SLB-A explained that they had difficulty in conveying learning to students using an online system. Besides the facilities which is inadequate, she has never received training and guidance in giving learning to students with special needs with an online system. Finally, all the assignments she had to give to students, done by the parents of those students as a whole in house. It has been going on since March 2020. She said that students did not receive effective learning during the COVID-19 pandemic. The ABK teacher from SLB-B Ambon said that she had to choose a learning method that was in accordance with the conditions of the ABK because not all ABK students could take lessons online but there were some students who needed to stay face to face such as autistic children and children who could not walk. She experienced problems in providing vocational learning and not all students have mobile. The teacher from SLB-C Batam said that many parents did not have time to accompany their children to study at home online and some children did not take online learning on time. And a teacher from SLBN-D Yogyakarta said that online learning is very ineffective because not all children and parents have a mobile and also a bad internet network. This condition requires a good adjustment so that the ABK teachers can accept that reality to avoid stress, low self-esteem in overcoming problems faced which could have an impact on their quality of life. Tonon [11] defines that the Quality of life as an individual's view with regard to expectations, interests, and achievements in the culture or value system it embraces. Meanwhile, the WHOQOL
Group [12] says that quality of life is subjective is each person, is a multidimensional concept that can be viewed from a positive and negative. There is not much research on the quality of life of teachers, especially $\mathrm{ABK}$ teachers researched, especially in Indonesia. With many limitations both on the part of students and ABK teachers in online learning, therefore, researchers are interested in knowing the picture of the quality of life of $A B K$ teachers during the COVID-19 pandemic in Indonesia.

\subsection{Quality of Life}

Quality of life is the provision of meaning by individuals regarding conditions life, in the context of socio-culture and values, relating to hope goals, standard of living, and what is desired. It is further stated that the quality of life based on the views and personal feelings of each person, from a positive point of view and negative, and is a multidimensional concept The WHOQOL Group [12]

Tonon [11] defines quality of life as the view of individuals who are associated with expectations, beliefs, interests, and achievements in socio-cultural or the values it has. Quality of life is also about how big the suitability of individual life with expectations, how satisfied the individual is of his life, and an understanding of individual elements that are not yet in accordance with expectations and needs to be changed.

Furthermore, Felonneau and Causse [13] explain that quality of life is an individual's view of the state of his life in his environment and also has to do with the openness and enjoyment of the individual to parts contained in the environment in which he lives.

Based on the definitions described above, it can be said that quality of life is an individual's view of his or her existence, in context culture and values, related to expectations, desires, standards, and also purpose in life.

\subsubsection{The dimensions of quality of life}

Referring to the theory put forward by The WHOQOL Group [14], there is four dimensions of quality of life, namely physical health, psychological, social relations, and environment.

The physical dimensions address the physical condition of the individual. Physical problems covered in the physical dimension are the activities carried out by the individual every day, present or not taking drugs and dependence on drugs, as well as therapy certain, reduced energy and fatigue, body movements, pain and discomfort, rest and sleep, and strength in carrying out activities [14].

The psychological dimension addresses the psychological condition of the individual. Psychological problems included in the psychological dimension are body images and appearances; that feeling pleasant and unpleasant, a feeling of worth and quality; belief and individual faith; and the ability to solve problems, remember, understand, assessing and reasoning [14].

The social relation dimension discusses individual social relationships and interactions with other people in the neighbourhood. Social relations problems are covered in 
this dimension is relationship and personal interaction, attention, appreciation, enthusiasm, acceptance, as well as forms of help, support and assistance from the community and environment, as well as sexual activity [14]. The environmental dimension discusses the state of the environment which is the place individuals live their daily lives. The problem covered in the dimension environment are factors that can support economic conditions; independence within act and behave, physical comfort, and security; access and quality of facilities health and social care; residential conditions, opportunities to gain knowledge; participate and the opportunity to enjoy the environment; condition around the house, which includes pollution, noise levels, traffic and climate; and transportation [14].

\subsubsection{Factors affecting quality of life}

According to Tapia-Fonllem, Corral-Verdugo, and FraijoSing [15] there are five factors which can affect quality of life. These factors can improve quality of life for individual life if done continuously. The five factors referred to are pro-environmental behaviour, simplicity, altruism, justice, and social capital.

The first factor by Corral-Verdugo in Fonllem et al [15] is pro-environmental behaviour. Pro-environmental behaviour is everything efforts made by individuals consciously and effectively to maintain and maintain nature [15]. Activities that can be done includes activities to process waste into new materials and have use values, using sufficient water and electricity, making organic fertilizers, and cultivating by public vehicle.

Based on the research that has been done, proenvironmental behaviour can improve the quality of life as all the activities undertaken can create the environment becomes regular, clean, fertile, productive, comfortable and conducive in place where the individual is. It can also increase comfort, serenity, happiness, satisfaction and individual welfare, so that it has a positive impact on the quality of life of individuals [15].

The second factor is simplicity. Simplicity is an individual's daily behaviour to use products as needed; without going overboard. Research indicates that an increase in income and an increase in the use of products is not always increases individual happiness, however, the ability of individuals to control themselves against the use of products that are not needed is one aspects that can increase satisfaction and this is very influential on quality individual life [15].

The third factor is altruism. Altruism is a positive behaviour that is carried out continuously for the welfare of other people's lives. This behaviour is carried out sincerely, without waiting for rewards from others, and this positive behaviour results in good and helping others for a long period of time. Altruistic behaviour performed individuals can improve the quality of life of individuals because of this behaviour, closeness, sense of belonging and confidence with others will increase, as well as can build quality relationships and social interactions with others [15].
The fourth factor is justice. Justice in an environment can be created when the individual feels the application of law and human rights is not discriminatory. Justice in question includes social justice, justice in access and health, education, and opportunities for work. Research shows that individuals who feel the existence of justice in their environment will feel more comfortable, free, satisfied, and happy, which in turn also improves the quality of his life [15].

The fifth factor is social capital. Social capital shows involvement individuals in social groups in the community where they live. As is involvement of each individual, the individual will feel socially connected, that can increase the attitude of please help, as well as the trust between members who can provide a positive impact on the lives of each member. Social capital can improve the quality of life because individuals have groups that support each other, can cooperate, and connect with one another, and can be trusted [15].

Currently, the world is hit by a third outbreak of the virus, the so-called SARS-CoV-2 outbreak with Covid-19. The transmission of Covid-19 has been proven from human to human and was first discovered in the city of Wuhan-China [16]. This Covid-19 infection is characterized by fever and cough. Individuals with more Covid-19 Severe symptoms will have acute respiratory distress and lung damage to experiencing inflammation and pneumonia. [17] This can increase the morbidity and mortality rates.

Because of this Covid-19 spread throughout the world, the WHO [18] calls it as a pandemic. The existence of the Covid-19 pandemic requires the Indonesian government to issue various policies to reduce the spread of Covid-19 in various regions. Public who previously worked and had activities outside the home, now they are doing work and activities from home which Purwanto [19] calls Work from Home (WFH). Thus, educational institutions both private and public education participate adapting to this policy, namely learning and teaching from home or what is called Distance Learning (PJJ) using the internet network [20]. Republic of Indonesia government policy in implementing learning in the future The Covid-19 pandemic is explained in the New Academic Year Letter of Study [21], namely by using the PJJ system for schools which is in the orange zone to the red zone in accordance with government stipulations local. Since the implementation of PJJ by the government, the role of teachers is very large, starting from the role of teachers in early childhood education to universities. Muhson [22] says that teacher is a profoundly noble profession world of education as a source of knowledge and knowledge for all students and students. Meanwhile, according to Pojoh [23], students are the designation of students starting from Elementary School (SD) to Senior High School (SMA) students. Students SD and SMA are part of the education system that is educated in order to become individuals who are qualified and can compete in a healthy manner. With the PJJ System, the teachers still required to be able to provide learning to students and students without reducing the quality of education. The definition of teachers of children with special needs according to Zaharah [24] is an important part of education 
that has teacher education and served as educator's / teaching staff at the Special School (SLB).

According to the Government Regulation of the Republic of Indonesia Number 72 of 1991 [25] concerning Special Education, special education is education that is devoted to students with physical or mental disabilities. In Indonesia through Regulation the Minister of Education of the Republic of Indonesia No. 33 of 2008 [26] has five types of disabilities, namely blind, deaf, mentally handicapped, disabled, and disabled. Further explained that special education units are schools that provide special education or often called SLB. As for the purpose of this extraordinary education according to the Regulations the Government of the Republic of Indonesia Number 72 of 1991 [25] is helping students who have a physical or mental disability in order to be able to build attitudes, knowledge and skills as individuals and members of society in interacting with social environment, and natural surroundings and can develop capabilities in the world work or attend further education.

Online system learning is different from offline system learning. System offline according to Sunendar et al in Mulyana [27] is learning that is not connected to a computer network, meaning that offline system users meet in person and face to face and learn through books owned by students and teachers. Meanwhile, Mulyana [27] said that learning using an online system is a form of learning where users use interactive models and learning Management System (LMS). Online system users in this learning are at different places; there is no in person meeting. Simanihuruk et al [28] mentions that learning using the internet network is called online learning systems or virtual learning (online). Hasibuan et al in Mulyana [27], states that online system learning is usually done with using Zoom, Google Meet, Google Drive, and so on. He continued he explained that these online activities included webinars, online classes, and all activities are carried out using the internet and computer networks.

The challenges in the learning process are getting bigger and more varied especially for special school teachers (SLB) who teach students with needs specifically [29]. Thus, the learning process at the moment it has many changes. ABK teachers are expected to be able to do PJJ with adapt to online systems. The transition from offline learning systems to systems PJJ until an undetermined time forces teachers and special needs teachers to be more creative. Supriyadi in Priyanto [30] said that the creativity is a form of effort and the ability of teachers to adapt because able to provide new things through his ideas and works. However, creativity will be hampered if the facilities are inadequate and lacking teacher competence. This is both a burden and a challenge that teachers must understand what students need and how to maximize the process learning during the COVID-19 pandemic. Problems can occur in the environment education due to limited facilities and lack of resources, competence as well skills. According to Pujilestari [31] the government still allocates minimal funds for educational needs so that not all educational institutions have access facilities an adequate Information Technology (IT) network. Even though PJJ is enforced, however not all students and even ABK teachers can do and follow the system PJJ is well and maximally. Shackelfort and Goetz [32] and Calhoun and Acocella [33] said that adaptation is an individual's adjustment to the environment new so that he is able to interact with other people and a new environment. When the individual is not able to adapt, then various problems and conflicts will arise. Conflict which arises will certainly affect the quality of one's life.

\subsection{Our Contribution}

Research advice and benefits can be given to the world knowledge body of educational psychology and health psychology. The quality of life for ABK teachers can be maintained and improved even during the COVID-19 pandemic. This is a suggestion for further researchers to develop research by adding new variables that can examine factors that can improve the quality of life of $\mathrm{ABK}$ teachers in difficult times such as pandemic COVID-19. Future research is expected to be able to calculate the proportion of SLB with a clear name of SLB so that it can calculate the proportion of SLB. And suggestions relating to Practical Benefits Based on the research that has been done, advice can be given to teachers with special needs to understand their quality of life and be able to sustain it with various efforts during the COVID-19 pandemic because their quality of life is very much needed in the world of education. In addition, suggestions were also given to the school administration to continue to provide support for the quality of life of the ABK teachers so that they remain high. Likewise, to the government, supporting and facilitating ABK teachers in maintaining their quality of life during the COVID-19 pandemic.

\section{METHODS}

\subsection{Research Participants and Design}

Participants in this study were 101 teachers of children with special needs, who were categorized as early adults and middle adults aged 20-65 years. This research is not limited by religion, education level, gender, occupation, and domicile. The design of this research is non-experimental quantitative, using tools measure in the form of a questionnaire. The sampling technique in this research is technique purposive sampling, which means that participants are obtained based on availability and willingness to fill out a questionnaire.

\subsection{Research Settings and Instruments}

This research will be conducted January 2021 in five SLB, they are SLB-A in Sumatera Utara, SLB-B in Ambon, SLB$C$ in Batam ,SLBN-D in Yogyakarta, and SLB-E Pembina Provinsi Kalimantan Timur. The research instrument that will be used in of two types. The first instrument is used to collect demographic data, which is in the form of a simple 
question about the identity of the ABK teacher, especially related with age, education, long serving as educators, learning methods are given before and during the Covid-19 pandemic. In the second instrument, questions were asked about the quality of life with using the Indonesian version of the WHOQOL-BREF measuring instrument, developed by Purba et al. [1]. The measuring instrument consists of 26 questions. Two of them measure overall quality of life and general health conditions of the participants. Meanwhile, the other 24 questions were divided into four dimensions, namely the physical dimension, psychological, social relations, and environment. The Indonesian version of the WHOQOL-BREF measuring tool using five Likert scale options, ranging from very poor (score 1) to very good (score 5).

Two items that measure the quality of life in general, namely item number 1 and item number 2 , have a Cronbach alpha coefficient of 0.637 and no items have a corrected item total correlation below 0.2 so that no items are discarded.

Table 1 Reliability and validity of general quality of life

\begin{tabular}{lll}
\hline & Alpha Cronbach & $\begin{array}{l}\text { Number of } \\
\text { Items }\end{array}$ \\
\hline Quality of Life & 0.637 & 2 \\
\hline
\end{tabular}

The first domain is the physical domain, consisting of 5 positive items (numbers 10, 15, 16, 17 and 18) and 2 negative items (numbers 3 and 4). This domain has a Cronbach alpha coefficient of 0.724. and no item has a corrected item total correlation below 0.2 so that no items are discarded.

Table 2 Reliability and validity of physical domain

$\begin{array}{ll}\text { Alpha } & \text { Number of } \\ \text { Cronbach } & \text { Items }\end{array}$

Quality of $0.724 \quad 7$

Life

The second domain is the psychological domain, consisting of 5 positive items (numbers 5, 6, 7, 11, and 19) and 1 negative item (number 26). This domain has a Cronbach alpha coefficient of 0.731 and no item that has a corrected item total correlation below 0.2 so that no items are discarded.

Table 3 Reliability and validity of the psychological domain

\begin{tabular}{|c|c|c|}
\hline & $\begin{array}{l}\text { Alpha } \\
\text { Cronbach }\end{array}$ & $\begin{array}{l}\text { Number of } \\
\text { Items }\end{array}$ \\
\hline $\begin{array}{l}\text { Quality of } \\
\text { Life }\end{array}$ & 0.731 & 6 \\
\hline
\end{tabular}

The third domain is the domain of social relations, consisting of 3 positive items (numbers 20,21, and 22). This domain has a Cronbach alpha coefficient of 0.526 and no item has a corrected item total correlation below 0.2 so that no items are discarded.

Table 4 Reliability and validity of the social relation domain

\begin{tabular}{lll}
\hline & $\begin{array}{l}\text { Alpha } \\
\text { Cronbach }\end{array}$ & $\begin{array}{l}\text { Number of } \\
\text { Items }\end{array}$ \\
\hline $\begin{array}{l}\text { Quality of } \\
\text { Life }\end{array}$ & 0.526 & 3 \\
\hline
\end{tabular}

In the fourth domain, namely the domain of the social environment, consisting of 8 positive items (numbers 8,9 , 12. 13, 14, 23, 24, and 25). This domain has a Cronbach alpha coefficient of 0.758 and there are item that have a corrected item total correlation below 0.2 so item 14 must be discarded.

Table 5 Reliability and validity of social environmental domain

\begin{tabular}{llll}
\hline & $\begin{array}{l}\text { Alpha } \\
\text { Cronbach }\end{array}$ & $\begin{array}{l}\text { Number } \\
\text { of Items } \\
\text { Before }\end{array}$ & $\begin{array}{l}\text { Number } \\
\text { of } \\
\text { Items } \\
\text { After }\end{array}$ \\
\hline $\begin{array}{l}\text { Quality of } \\
\text { Life }\end{array}$ & 0.758 & 8 & 7 \\
\hline
\end{tabular}

\subsection{Research Procedure}

Data collection will be done by distributing two types of questionnaires on $\mathrm{ABK}$ teachers in Indonesia. The researcher will ask for help from the $A B K$ teacher acquaintances for introducing their fellow $\mathrm{ABK}$ teachers to fill out two types of questionnaires the. Researchers will process the answers obtained to demographic questions participants and responses to item statements in their quality of life questionnaire. Data collection is stopped when the number of respondents has met the number of participants required. Some ABK teacher's acquaintances will be made as a coordinator in the G-form follow-up spread. The researcher will give a sign adequate thanks to the coordinators in accordance with the assistance it gives.

\subsection{Research Implementation}

Researchers collected data by distributing questionnaires on January 2021 to ABK teachers in SLB-A Sumatera Utara, SLB-B Ambon, SLB-C Batam, SLBN-D Yogyakarta, and SLB-E Pembina Provinsi Kalimantan Timur.

\subsection{Data Analysis Technique}

Data processing in this study will be carried out by descriptive analysis get a comprehensive picture of the quality of life of ABK teachers. The data received by the researcher will be processed using SPSS version 25. 


\section{FINDINGS AND DISCUSSIONS}

The sum of the mean empirical scores for all domains is greater than the hypothetical mean, which means that the participants' quality of life is high. Furthermore, based on the classification of the quality of life of the ABK teachers, from 101 participants it was found that 100 people with a percentage of $99.0 \%$ were at a high quality of life level and 1 other person with a percentage of $1.0 \%$ was low. From the above findings it can be said that although most teacher salaries are low, their quality is still high. Previously, researchers had asked all participants about their quality of life. Of the 101 participants, 9 participants said that their quality of life was low, and 92 participants were high. Based on the information found by the researchers, some participants did not answer honestly or inconsistently.

According to Tapia-Fonllem, Corral-Verdugo, and FraijoSing [15] there are five factors that can affect the quality of life, namely pro-environmental behavior, simplicity, altruism, justice, and social capital. Meanwhile, in a study conducted by Putri, Sukarti and Rachmawati [34], the quality of life for inclusive school teachers increased through an intervention, namely the provision of gratitude training.

Furthermore, the results of the analysis of this study indicate that there is no difference in the quality of life of the $\mathrm{ABK}$ teachers based on SLB origin, gender, age, marital status, and total income. However, the difference in quality of life was found based on the length of teaching in the physical domain where from the One Way ANOVA analysis, it was found that the quality of life was $F=3.859, p=0.006<0.05$, which means that the quality of life of the ABK teachers shows that there is a difference based on the length of teaching. The WHOQOL Group [14] explains that the physical domain discusses the physical condition of an individual which includes daily activities carried out by individuals, whether or not drug consumption, drug dependence or certain therapies, fatigue and reduced energy, body movement problems, pain. and discomfort, rest and sleep, as well as strength in activity.

Researchers also found differences in the quality of life of participant teachers based on the length of teaching seen from the physical domain. Thus the length of time for ABK teachers in teaching is considered the quality of life. The results of this study show that the quality of life for ABK teachers has a high quality of life during the COVID-19 pandemic. Suggestions for further research are to examine the reasons for the quality of life for ABK teachers in the high category during the COVID-19 pandemic through qualitative research. Future studies can add variables such as teacher efficacy other than quality of life to determine the relationship between quality of life and other variables. This study has limitation, because the researchers do not face to face with the participants therefore they cannot guide them directly.

\section{CONCLUSIONS}

Based on the results of data analysis carried out regarding the quality of life of the ABK teachers, it can be concluded that the quality of life for ABK teachers is high. The difference in quality was only found based on the length of teaching in the physical domain.

\section{ACKNOWLEDGMENT}

This work was funded by Institute of Research \& Community Engagement. The researchers are grateful to the Faculty of Psychology, Universitas Tarumanagara especially to the Dean of Psychology who has given the support for this International Collaboration research.

\section{REFERENCES}

[1] F.D. Purba, J.A.M. Hunfeld, A. Iskandarsyah, T.S. Fitriana, S.S. Sadarjoen, J. Passchier, J.V. Busschbach, Quality of life of the Indonesian general population: Testretest reliability and population norms of the EQ5D-5L and WHOQOL-BREF. PLoS ONE 13(5) (2018), e0197098. https://doi.org/10.1371/journal.pone. 0197098

[2] H. Yang, P. Bin, A. J. He, Opinions from the epicenter: an online survey of university students in Wuhan amidst the COVID-19 outbreak1, Journal of Chinese Governance, 2020, pp. 1-15. DOI: 10.1080/ 23812346.2020.1745411

[3] World Health Organization, WHO coronavirus disease (COVID-19) dashboard, 2020, September. https://www.who.int/

[4] Kementerian Kesehatan Republik Indonesia, Situasi covid 19, 2020 September. https://www.kemkes.go.id/

[5] J. Lee, Mental effects of school closures during covid 19, Journal of Child \& Adolescent, 4 (2020) 421.DOI: https://doi.org/10.1016/S2352-4642(20)30109-7

[6] S. Donitsa-Schmidt, R. Ramot, Opportunities and challenges: teacher education in Israel in the Covid-19 pandemic, Journal of Education for Teaching, 2020, pp. 1-10. doi:10.1080/02607476.2020.1799708

[7] R. Bhat, V.K. Singh, N. Naik, C.R. Kamath, C. R, P. Mulimani, N. Kulkarni, COVID 2019 outbreak: The disappointment in Indian teachers, Asian Journal of 
Psychiatry, 50 (2020) 102047. DOI: 10.1016/ j.ajp.2020.102047

[8] K.J.B. Talidong, C.M.D. Toquero, Philippine teachers' practices to deal with anxiety amid COVID-19, Journal of Loss and Trauma, 2020, pp. 1-7. doi:10.1080/15325024.2020.1759225

[9] C.T.S. Rokhani, Pengaruh work from home (WFH) terhadap kinerja guru SD negeri Dengkek 01 Pati selama masa pandemi covid, Jurnal of Education, Psychology and Counseling, 2(1) (2020) 2716-4446. https://ummaspul.ejournal.id/Edupsycouns/article/view/ $500 / 292$

[10] Tribun Jabar, Dengan santai menghina guru makan gaji buta karena sekolah tak kunjung buka, pria ini langsung dihajar oleh para guru yang ngamuk dan dilaporkan ke polisi: Dia tidak merasakan sulitnya bikin materi daring, 2020, 30 July. https://www.grid.id/read/ 042268189/dengan-santai- menghina-guru-makan-gajibuta-karena-sekolah-tak-kunjung-buka-pria-inilangsung-dihajar-oleh-para-guru-yangngamuk-dandilaporkan-ke-polisi-dia-tidak-m.

[11] G. Tonon, Relevance of the use of qualitative methods in the study of quality of life. Dalam G. Tonon (Eds.), Qualitative studies in quality of life: Methodology and practice, Springer, Switzerland, 2015, pp. 5.

[12] The WHOQOL Group, The World Health Organization quality of life assessment (WHOQOL): Position paper from the World Health Organization. Social Science \& Medicine, 41(10) (1995) 1403-1409.

[13] M.L. Felloneau, E. Causse, Pro-environmentalism, identity dynamics and environmental quality of life. Dalam Fleury-Bahi, G., Pol, E., \& Navarro, O (Eds.), Handbook of environmental psychology and quality of life research, Springer, Switzerland, 2017, pp. 220.

[14] The WHOQOL Group, WHOQOL-BREF: Introduction, administration, scoring, and generic version of the assessment. Geneva: World Health Organization, 1996.

[15] C. Tapia-Fonllem, V. Corral-Verdugo, B. FraijoSing, B, Sustainable behavior and quality of life. Dalam G. Fleury-Bahi, E. Pol, \& O. Navarro (Eds.), Handbook of environmental psychology and quality of life research, Springer, Switzerland, 2017, pp. 177-181.

[16] Y. Bai, L. Yao, T. Wei, F. Tian, M.Y. Jin, L. Chen, M. Wang, Presumed asymptomatic carrier transmission of COVID-19. Research Letter, 323(14) (2020) 4061407. doi:10.1001/jama.2020.2565
[17] D. Blanco-Melo, B.E.N. Payant, W.C. Liu, S. Uhl, D. Hoagland, R. Møller, T.X. Jordan, K. Oishi, M. Panis, D. Sachs, T. T. Wang, R.E. Schwartz, J.K. Lim, R.A. Albrecht, B.R. TenOeve, Imbalance host response to SARS-CoV-2 drive development of covid 19. Cell,181 (2020) 1036-1045. https://doi.org/10.1016/j.cell.2020. 04.026

[18] World Health Organization, what is a pandemic? 2010, 24 February. https://www.who.int/csr/disease/ swineflu/frequently_asked_questions/pandemic/en/

[19] A. Purwanto, Studi eksplorasi dampak work from home terhadap kinerja guru selama pandemi covid 19 . Jurnal of Education, Psychology and Counseling, 2(1) (2020) 2716-4446.

[20] Kementerian Pendidikan dan Kebudayaan, Kemendikbud terbitkan pedoman penyelenggaraan belajar dari rumah, 2020. https://www.kemdikbud.go.id/ main/blog/2020/05/kemendikbud-terbitkan-pedoman penyelenggaraan-belajar-dari-rumah

[21] Keputusan Bersama Menteri Pendidikan Dan Kebudayaan, Menteri Agama, Menteri Kesehatan, Dan Menteri Dalam Negeri Republik Indonesia, Surat Pembelajaran Tahun Ajaran Baru di Masa Pandemi Covid-19, 2020.

[22] A. Muhson, Meningkatkan professionalisme guru: Sebuah harapan. Jurnal Ekonomi dan Pendidikan, 2(1) (2004) 90-98

[23] S. Pojoh, et al, Sistem pendukung keputusan untuk menentukan siswa berprestasi yang layak menjadi siswa teladan. E-Jurnal Tehnik Informatika, 8(1) (2016) 23018364

[24] I. Zahara, Meningkatkan kemampuan penjumlahan bilangan 1-20 melalui model pembelajaran creative problem solving dengan video compact disk (VCD) pada anak tunarungu, Jurnal Ilmiah Pendidikan, 1(2) (2020) 202-212. http://ejournal.unp.ac.id/index.php/jupekhu

[25] Peraturan Pemerintah Republik Indonesia No 72 tahun 1991. Tentang pendidikan luar biasa (Pasal 1. No. 1). Jakarta, Presiden Republik Indonesia.

[26] Peraturan Menteri Pendidikan Nasional Republik Indonesia Nomor 33 tahun 2008. Tentang standar sarana dan prasarana untuk Sekolah Dasar Luar Biasa (SDLB), Sekolah Menengah Pertama Luar Biasa (SMPLB), dan Sekolah Menegah Atas Luar Biasa (SMALB) (Pasal 1. No.39) Jakarta, Menteri Pendidikan Nasional

[27] A. Mulyana, Pelaksanaan pembelajaran daring dan luring dengan metode bimbingan berkelanjutan pada 
guru sekolah dasar di Teluk Betung Utara Bandar Lampung, Jurnal Ilmiah Pendidikan Dasar Indonesia, 2(1) (2020) 67-76.

[28]. L. Simanihuruk et al, E-learning: Implementasi, strategi, dan inovasinya. Yayasan Kita Menulis, 2019

[29] M.N. Jauhari, Sambira, Z. Zakiah, Dampak pandemi covid-19 terhadap pelaksanaan pemeblajaran penjas adaptaif di sekolah luar biasa, Journal STAND: Sports and Development, 1 (2020) 63-70. http://jurnal. unipasby.ac.id/index.php/stand/about/submissions

[30] A. Priyanto, Pengembangan kreativitas pada anak usia dini melalui aktivitas bermain. Jurnal Ilmiah Guru, 2 (2014) 41-47. file:///C:/Users/Asus/AppData/Local/ Temp/2913-7623-1-PB.pdf

[31] Y. Pujilestari, Dampak positif pembelajaran online dalam sistem pendidikan Indonesia pasca pandemi Covid-19, Buletin Hukum dan Keadilan, 4(1) (2020) 4956. DOI:10.15408/adalah. v4i1.15394

[32] T.K. Shackelfort, A.T. Goetz, Adaptation to sperm competition in humans, Psychological Science,15(1) (2007) 643-649.

[33] J.F. Calhoun, J.R. Acocella, Psikologi tentang penyesuaian dan hubungan kemanusiaa, Edisi Ketiga, Alih bahasa: Ny. RS. Satmoko, IKIP, Semarang, 2004

[34] D.A. Putri, M.A. Rachmawati, Pelatihan kebersyukuran untuk meningkatkan kualitas hidup guru sekolah inklusi, Jurnal Intervensi Psikologi, 8(1), 21-40. 